\title{
The Influence of Knowledge Management on Satisfaction and Job Performance: A case study of Lecturers at Vietnam National University, Hanoi
}

\author{
BINH DINH LE* \\ School of Business Administration, University of Economic and Business \\ Vietnam National University, Hanoi \\ 144 Xuan Thuy Street, Cau Giay, Hanoi \\ VIETNAM \\ NAM HOANG DO \\ University of Social Sciences and Humanities; International School, \\ Vietnam National University, Hanoi \\ 144 Xuan Thuy Street, Cau Giay, Hanoi \\ VIETNAM \\ THAO THI LE \\ The Center for Knowledge Transfer and Startup Support \\ Vietnam National University, Hanoi \\ 144 Xuan Thuy Street, Cau Giay, Hanoi \\ VIETNAM \\ VUONG PHAM \\ The Center for Education Accreditation \\ Vietnam National University, Hanoi \\ 144 Xuan Thuy Street, Cau Giay, Hanoi \\ VIETNAM
}

\begin{abstract}
This scientific article aims to examine the relationship of knowledge management, satisfaction and task performance of lecturers of Vietnam National University, Hanoi. In this study, the authors have used the exploratory factor analysis (EFA) tool and based on the analysis of survey sample for 200 lecturers working at Vietnam National University, Hanoi. The research results show that: Knowledge management has a positive impact on job satisfaction and performance; Satisfaction of lecturers plays the role of a partial mediator between knowledge management and job performance. From the research results of the article, Vietnam National University, Hanoi has clearly understood the relationship between knowledge management, satisfaction and assigned job performance, thereby being possible to develop plans and strategies to improve the performance of organization.
\end{abstract}

Key-Words: - Knowledge management; satisfaction; creative knowledge, job performance; knowledge application; lecturers.

Received: April 16, 2021. Revised: November 23, 2021. Accepted: December 5, 2021. Published: December $17,2021$.

\section{Introduction}

Knowledge management plays a particularly important role in any organizational model. Especially universities - which are considered to have the highest knowledge content with the goal of creating new knowledge, the role of knowledge management factor has a strong impact and comprehensive and profound influence on individuals (administrators, lecturers, staff and learners) and the entire operation of such universities (admission, training organization, scientific research, 
administration, education quality assurance and other activities).

Vietnam National University, Hanoi is a highquality, multidisciplinary and multi-field knowledge and technology transfer, scientific research and training center which is on a regional level, gradually reaching the international level; meeting the development requirements of the country, in line with the development trend of advanced higher education. Vietnam National University, Hanoi operates under a mechanism of autonomy and high self-responsibility; working directly with ministries, ministerial-level agencies, government-attached agencies, Provincial and Municipal People's Committee on issues in relation to the operation and development of Vietnam National University, Hanoi. The affiliated universities and scientific research institutes of Vietnam National University, Hanoi are training and scientific and technological research institutions with high autonomy and legal entities equivalent to other universities and scientific research institutes prescribed in Law on Education, Law on Higher Education, Law amending and supplementing a number of articles of Law on Higher Education and Law on Science and Technology.

As of December, 2020, in terms of scientific staff with doctoral degrees or higher, Vietnam National University, Hanoi has 1,348 doctors and doctors of science (reaching 57\%); 422 professors and associate professors (60 professors, 362 associate professors), reaching $19 \%$, nearly 3 times the national average percentage (Vietnam National University, Hanoi, 2021). With a team of highly qualified lecturers, holding the leading role, Vietnam National University, Hanoi is really the "leader" to lead and support its universities / other universities in the country to operate effectively and to carry out the mission of training highquality human resources. Vietnam National University, Hanoi is known as an example of knowledge management, in which, the role of knowledge management is considered to be the driving force and the condition bringing satisfaction and job performance for its lecturers.

\section{Chart 1. Lecturers of Vietnam National}

\section{University, Hanoi in the last 5 years}

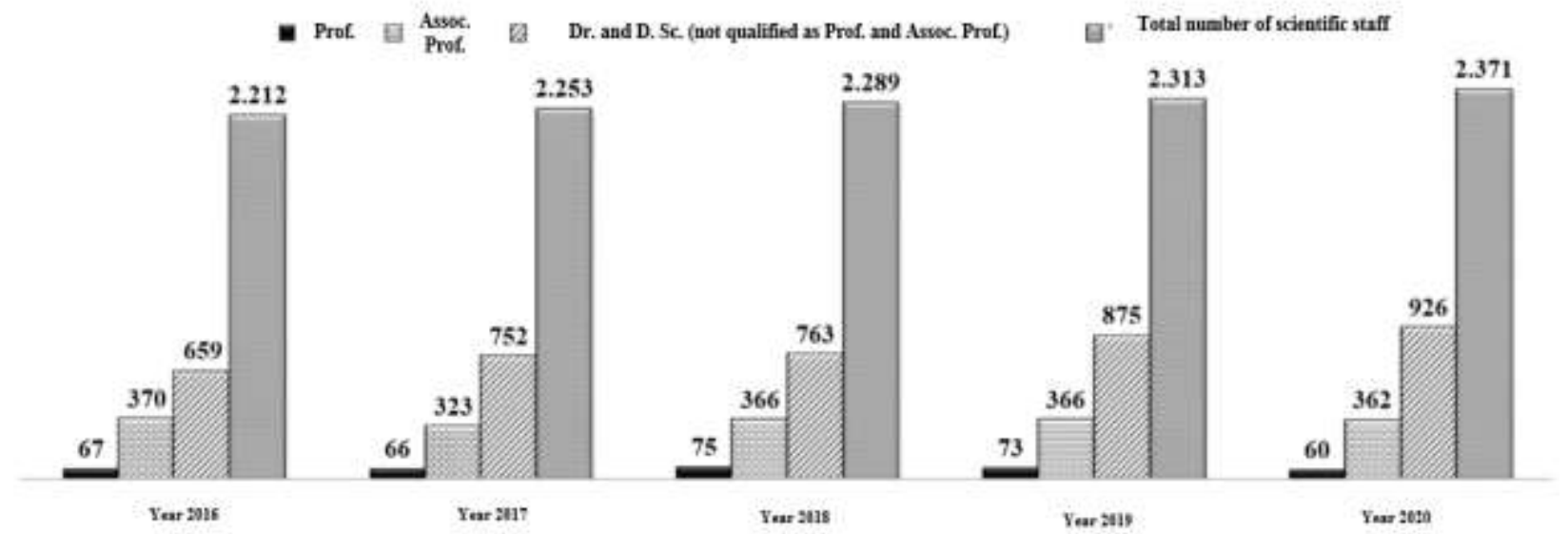

(Source: Author compiling from annual reports of Vietnam National University, Hanoi)

The research on relationship between knowledge management - satisfaction - job performance of lecturers of Vietnam National University, Hanoi is a serious and necessary scientific task to measure and assess the level of impact of knowledge management on satisfaction and job performance of lecturers. Since then, make suggestions and solutions to improve and enhance the satisfaction and job performance of lecturers, thereby improving quality and performance of Vietnam National University, Hanoi. 


\section{Literature review and hypothesis development}

\subsection{Knowledge}

Knowledge, in accordance with the Oxford English Dictionary, is facts, information, or skills acquired through experience or through education; theoretical or practical understanding of a thing. In epistemology, the science researching knowledge, knowledge is defined as a justified true belief. In simple terms, knowledge is facts, information, or skills, which have been tested for correctness in practice and gained the trust of users.
The basic feature of knowledge is that it can be exchanged, transferred from one object to another, used many times and bring added value to the enterprise. The knowledge development pyramid model (Figure 1) of Bender and Fish shows the process of knowledge formation. In which, data is just numbers, values, phenomena collected systematically. Data is added its value by adding meaning and understanding through human interpretation which will become information. Information will transform into knowledge when reinforced by beliefs after use. Expertise is obtained when knowledge is enriched, distilled, combined with other knowledge through repeated experience, research, training

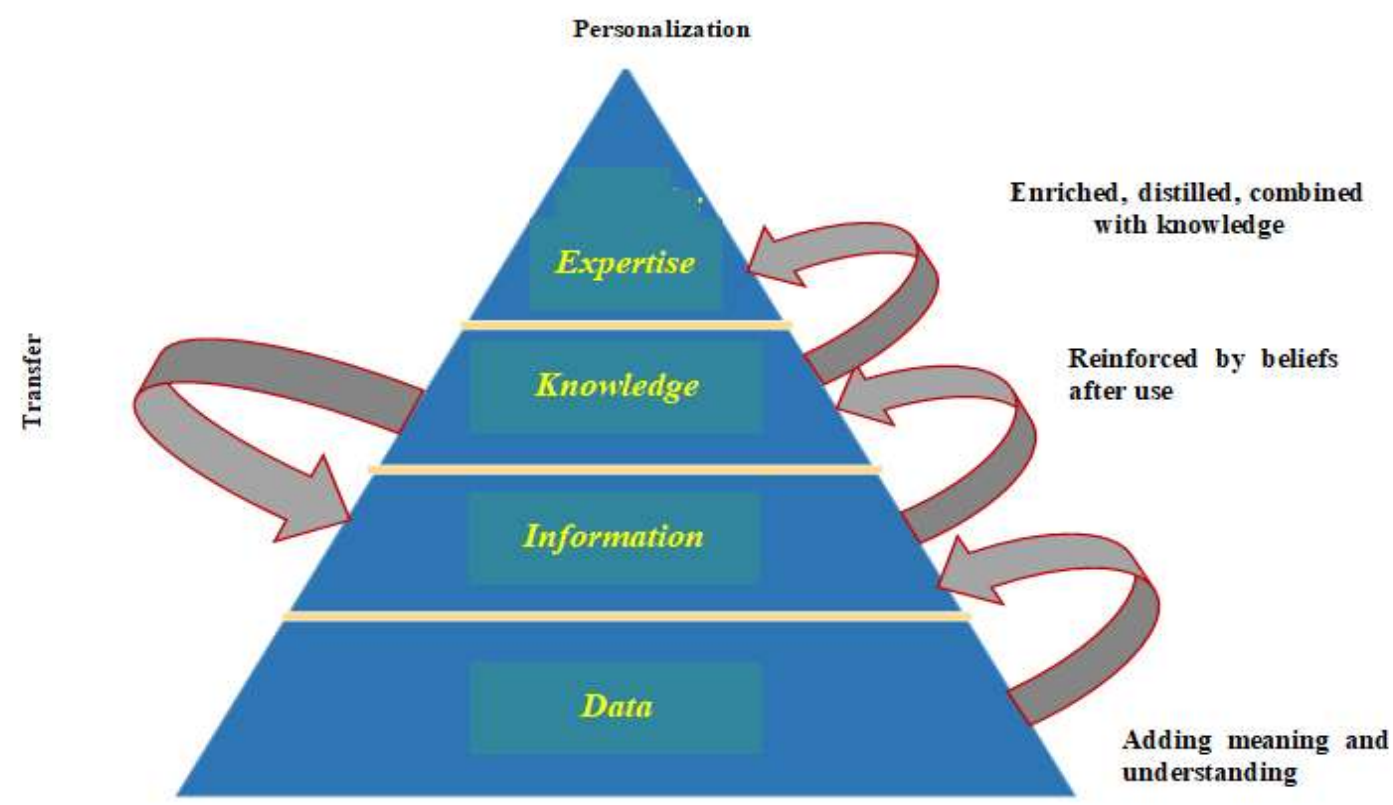

\section{Figure 1. Knowledge development pyramid model (Source: Bender and Fish, 2000)}

This level of knowledge as "wisdom". In accordance with this pyramid model, the higher it goes, the more valuable knowledge. However, it is more difficult to share and transfer. The levels of data, information and knowledge are potentially easier to manage, share and transfer [1] Apurva and Singh (2011).

There are many ways of classifying knowledge. However, for ease of application to knowledge management in enterprises, knowledge is usually divided into two types: Explicit knowledge: being possible to be recorded and expressed in the form of documents, audio, images, digital files and be easily stored, transferred, shared on the information technology infrastructure or through the process of training, instruction, knowledgesharing activities; Tacit knowledge: formed from actual experience, or through in-depth research and stored in specific human brains (for example: beliefs, experiences, know-how), which have not 
been recorded and express in explicit form. Tacit knowledge may remain hidden forever and disappear with the departure of a particular person. However, tacit knowledge in an individual can be transformed into tacit knowledge in another through an exchange, cooperation, and training. Tacit knowledge can also partially become reality if it is narrated, documented, videotaped, recorded, etc., and then shared across an information infrastructure of an enterprise. The relationship between explicit knowledge and tacit knowledge can be modeled through the following model. Explicit and tacit knowledge of humans is associated with the level of human activity. This is shown in the Figure 2:

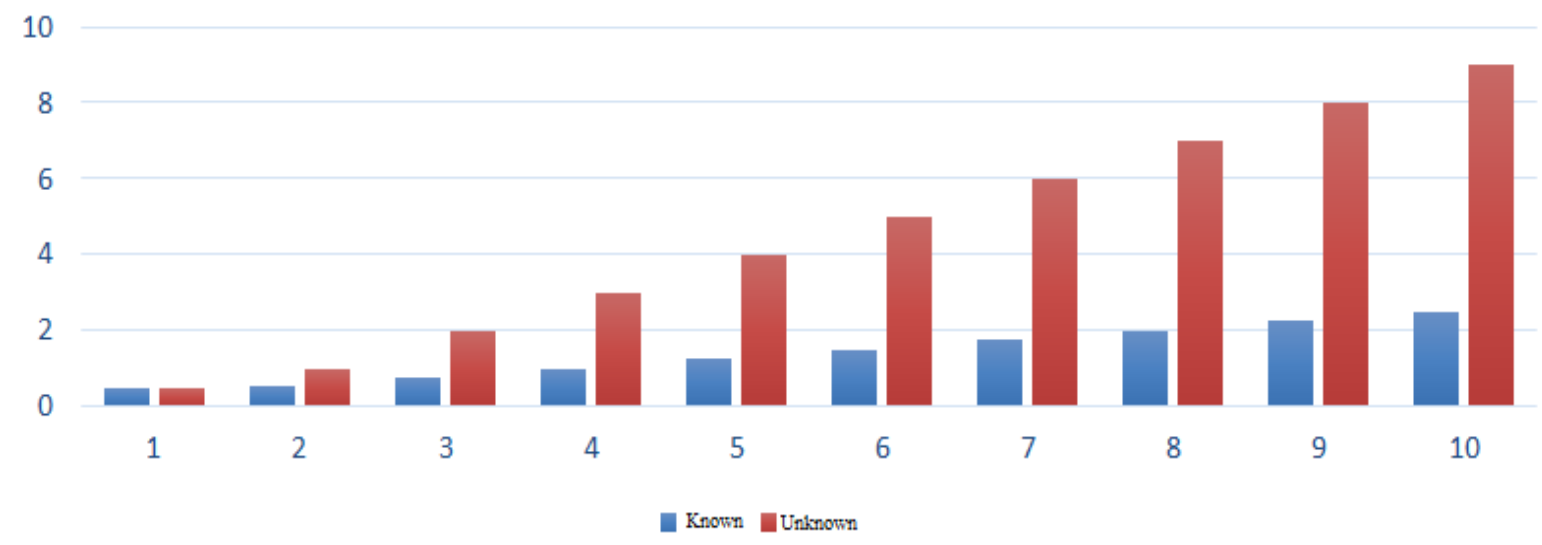

(Note: Indicators from 1 to 10 are for illustrative purposes only)

Figure 2. Correlation between tacit knowledge and explicit knowledge

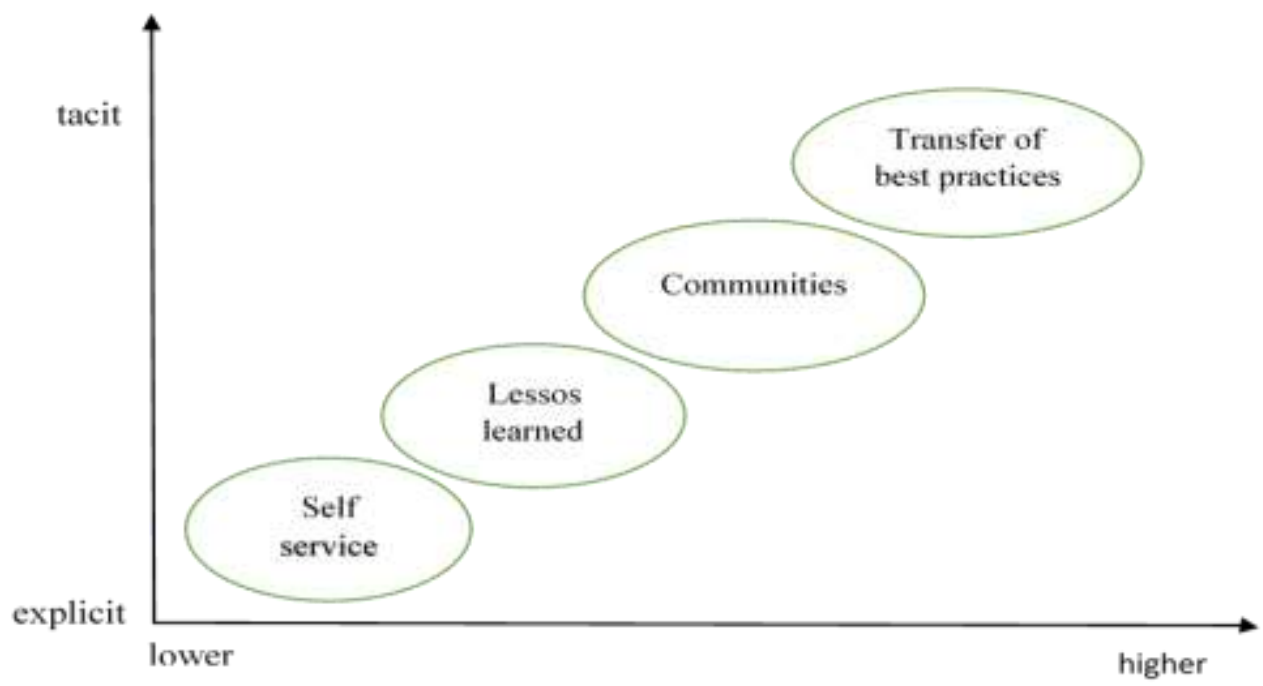

Human interaction

Figure 3. The interaction of human activity and knowledge 


\subsection{Knowledge management}

Currently, there are many definitions from different angles of the concept of knowledge management and administration. In English, there is only one concept, knowledge management. Knowledge management is about bringing knowledge to the right person at the right time, helping that person make the best decision [2] Petrash (1996). Reid Smith, Deputy General Director of Knowledge of Schlumberger said that knowledge management is about creating a working environment where knowledge and experience are easily shared, then applied by individuals to make optimal decisions in real time.

The most complete view is that of Dalkir (2005) when he thought that knowledge management is the systematic and deliberate coordination of human, technological, process and organizational factors to increase value through the reuse and creation of new knowledge. This coordination process includes creating, sharing, applying knowledge and receiving feedback with lessons learned, best practices, enriching memory and maintaining the continuous learning process of enterprise.

Knowledge management in universities or businesses operating in the field of education needs to be adapted and flexible. The author believes that, under the impact of digital transformation, the content of expert knowledge and creative knowledge will increase in both quantity and quality; surprises for managers. Therefore, knowledge managers in the context of digital transformation need to emphasize and simultaneously implement all four factors: knowledge creation; knowledge acquisition, knowledge sharing and knowledge application; It should be considered a principled process [3] Inese Mavlutova et al (2020).
Several universities in Hungary show that knowledge management has a strong impact on job satisfaction and performance among participants in this field; Knowledge management skills of leaders are one of the factors that bring about employee satisfaction and increase labor efficiency [4] László Berényi, Nikolett Deutsch (2020).

Comparative study of technology models in the stages of implementing Web 2.0 technology; 3.0 and 4.0 to show the strong development of the role of knowledge management elements in the problem of creating new knowledge. In addition, the author also shows and describes how associative learning contributes to knowledge creation. The author also predicts that blended learning model will be one of the popular trends in higher education in the future. Accordingly, knowledge management also exhibits associative and mixed nature as its inherent nature [5] Juan Carlos et al (2020).

Knowledge management plays an important role in simulating the process of using and developing big data systems in universities. Accordingly, knowledge management is inseparable from big data and big data technology will require knowledge management skills in universities to change; It is big data technology that will create new knowledge [6] Patricia Marybelle Davies et al (2020).

Thus, knowledge management is the management of the life cycle of knowledge: creating/capturing knowledge; standardizing to store under a searchable and accessible scientific structure; sharing to enrich knowledge and improve the capacity of individuals; creating conditions for individuals to use, creating added value for enterprises; simultaneously receiving feedback during the use to confirm the value of knowledge or update/refresh so that knowledge enters a new life cycle. 


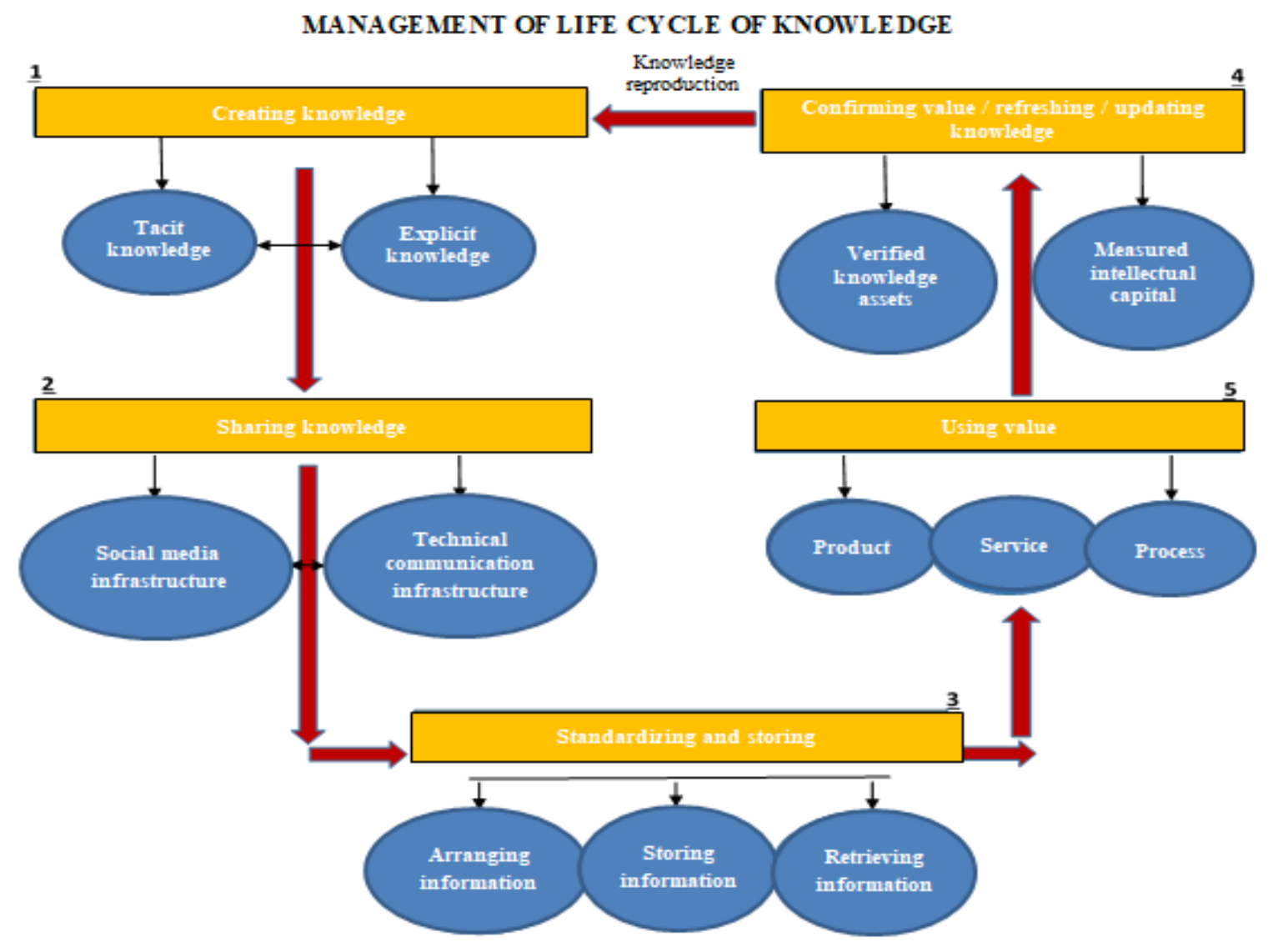

Figure 4. Management of life cycle of knowledge

The above definitions show that, in knowledge management, there are 4 tangible main points: (1) information technology infrastructure being capable of systematizing, storing and sharing explicit knowledge; (2) community practicing knowledge management, including those who are willing to capture, share and use knowledge, especially knowledge being still in tacit form; (3) encouraging policies, procedures, processes and guidelines for knowledge management practices, including methods and tools for capturing, sharing and using knowledge; (4) the unit specialized in knowledge management, with the core of a small group of professional knowledge managers, being responsible for developing policies, procedures, guidelines, sharing good practices in knowledge management, coordinating the operation of the system consisting of the above components; measuring target criteria, receiving feedback to improve the system.

\subsection{Satisfaction of lectures in teaching and research}

In higher education, employees are mainly lecturers who directly impart knowledge to learners. Lecturers are considered an important factor determining the quality of education. Job satisfaction of lecturers (teaching and research) is one of the important working motivations of lecturers and is often considered as one of the bases for assessing the quality of human resources of a university [7] Sharma \& Jyoti, (2009). Therefore, understanding the factors affecting satisfaction of lecturers in the workplace is crucial for the success of a university.

The satisfaction of lecturers may be influenced by internal factors, extrinsic factors and demographic variables [7]. The satisfaction of lecturers is the satisfaction with the results achieved by the lecturers during the teaching process. In 
accordance with the study of Williams and Reavis (2009), the satisfaction of lecturers is the driving force motivating lecturers to work and stick with teaching and research. These researchers believed that the satisfaction of lecturers is expressed through satisfaction with the following factors: (1) salary and salary increment, (2) promotion opportunities, (3) manager, (4) rewards (not necessarily money), (5) working rules, procedures and conditions, (6) colleagues, (7) nature of work performed and (8) information in an organization. This study was an iterative study at a new site. Accordingly, the research model (Figure 1) is based on the results of a number of aforesaid studies. With the nature of such an iterative study, this study selectively inherits some factor scales of previous researchers such as: Lester (1987), Sharma and Jyoti (2009), Best (2006), Billingsley (2004), McKee (2003), and Denlinger (2002).

The job satisfaction shows the extent to which employees have a positive perception and orientation towards their jobs in the organization, and job satisfaction is defined and measured in two aspects: (1) General satisfaction, expressing common feelings on all aspects of work [8] Kianto et al., (2016); and (2) Satisfied with each aspect of the job such as: Salary, leadership, relationship with colleague. When it is necessary to research and find a solution to complete each component aspect of job satisfaction, a satisfaction scale should be used for each component of the job. When it is necessary to research the effect of a certain activity or program on employee satisfaction with his/ her job, the concept and scale of general job satisfaction should be used.

When employees are satisfied, they tend to care more about the quality of their work, have more commitment to the organization, and have a higher engagement rate and, in general, they produce more products [9] Gibbs and Ashill (2013). A satisfied employee with his / her job will have a positive influence and bring more desired work values, improve efficiency and increase productivity [8]. Based on the above argument, this study proposed that.

\subsection{Job performance}

The job performance represents the quality and quality of work achieved by an individual or a group [10] Yang \& Hwang, (2014). Job performance of an individual is the work volume completed in proportion to the quality of work and the specific performance time. Assessment of job performance is to determine the level of job performance by a community or an individual in comparison with the set standards or with the job performance of other communities and / or individuals performing the same work [11] Tran Kim Dung, (2015).

Job performance is the output, or the outcome of a process, being the job completion with a level and objective accepted by a standard. That can be measured using a number of indicators such as: Work quality, performance, productivity, training effectiveness, judgment, punctuality, behaviour and personality [12] Tseng and Huang (2011),

On a narrow scale, job performance represents the quality and quality of work; on a large scale, job performance can be further measured by behavioural, personality, self-development, cognitive, teamwork, or work efficiency criteria when comparing outputs with input costs [13] Hoang Hai Yen (2015). On the basis of an analysis of 58 studies culled from an analysis of 2,867 summaries of job performance studies, that different areas emphasize different aspects of job performance [14] Koopmans et al. (2011); Management focuses on how to make employees as productive as possible; while health focuses on how to prevent loss of productivity due to illness or poor health. There are 17 ways of measuring general job performance for many types of jobs and 18 ways of measuring job performance for each different type of job [14].

In Vietnam, job performance (teaching, research, community service) of lecturers are clearly shown in Circular No. 20/2020/TT-BGDDT by the Ministry of Education and Training stipulating the working regime of lecturers of higher education institutions. Accordingly, the stipulated working time of lecturers during the academic year is 44 weeks (equivalent to 1,760 office hours) to perform teaching, scientific research and community service tasks as well as perform other professional tasks, determined by the academic year after deducting the prescribed number of holidays. It is 
noticeable that this document does not stipulate rigidly the standard hours of lecturers in an academic year, but is stipulated with an extension of 200 to 350 standard teaching hours.

Accordingly, the autonomy of higher education institutions is expanded to specify within the permitted scope of the norm of standard hours, the conversion to standard hours and the scientific research task in accordance with the activity orientation of higher education institutions. In addition, this document has supplemented the tasks of tutors, specifically as follows: Participating in supporting lecturers with higher titles in teaching activities, inclusive of: Lecture preparation, tutoring, providing guidance on exercises, discussion, experiment, practice and marking papers. The assignment of tutoring activities, tasks, rights and benefits for those participating in tutoring activities shall be assigned to the head of higher education institution to specify.

At the same time, this document has also added online teaching hours and is specified as follows: Standard teaching hours is a unit of time converted from the number of labor hours required to complete a certain work volume under the task of lecturers equivalent to a the universitylevel period of teaching theory directly in class (or online teaching), including the necessary labor time before, during and after the teaching period. The teaching time in the training plan is calculated by standard teaching hours, of which a 50-minute is university-level period of teaching theory directly in class (or online teaching) is equal to one standard hour of teaching and specified in this document. For specific teaching contents, university-level period of teaching directly in class (or online teaching) for more than 50 minutes are assigned to the head of higher education institution to convert accordingly.

The norm of standard teaching hours of lecturers in an academic year is specified from 200 to 350 standard teaching hours (equivalent to 600 to 1,050 office hours); in which, standard hours of teaching directly in class (or online teaching) must ensure at least $50 \%$ of the prescribed norm. The head of higher education institution shall base on development goals and strategies of his/her unit, specific characteristics of subject and major, and specific conditions of his/her unit to decide the standard teaching hours of the lecturers in an academic year accordingly. Based on the above argument, this study proposed the following hypotheses:

Hypothesis 1: Knowledge management has a positive influence on lecturer's satisfaction.

Hypothesis 2: Knowledge management has a positive influence on lecturer's performance.

Hypothesis 3: There is a positive relationship between lecture's satisfaction performance.

The research model is demonstrated in Figure 5 below:

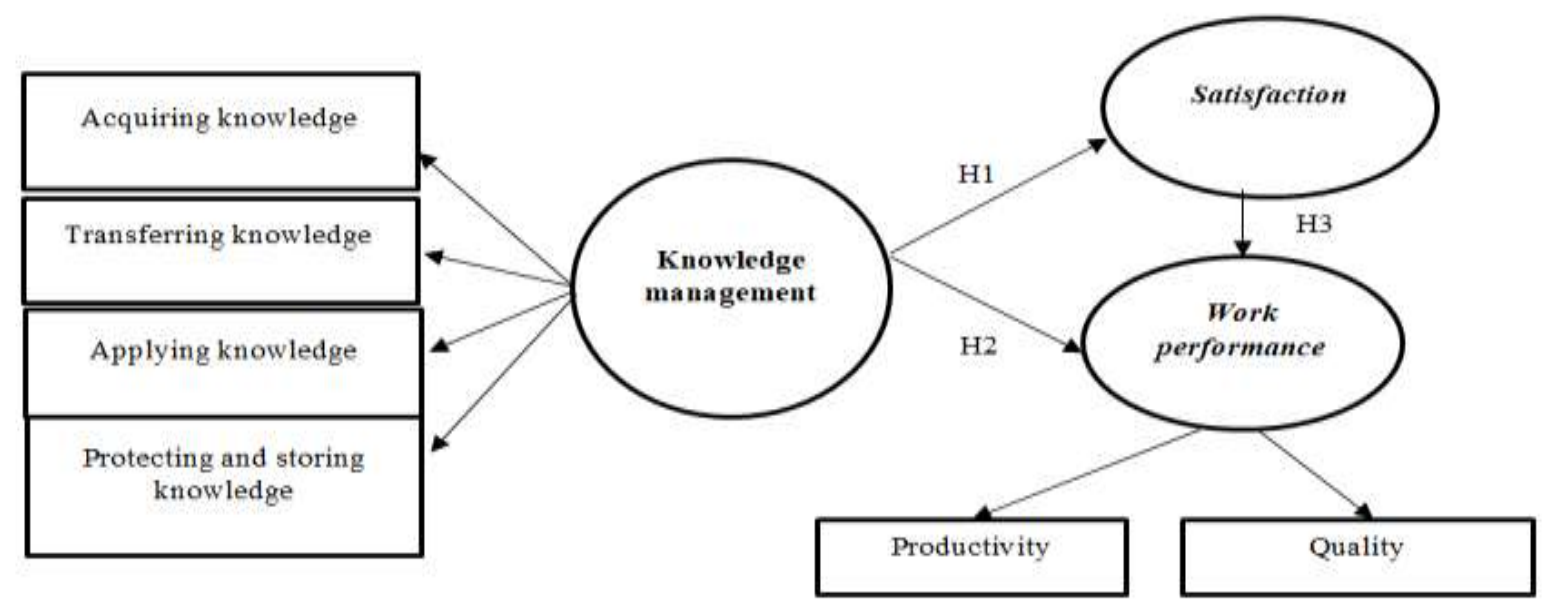

Figure 5. Research model 


\section{Characteristics of respondents}

This study applied quantitative analysis to analyze the data. The author conducted a survey using Google Form, sending it to 235 lecturers from universities/institutes of Vietnam National University, Hanoi. The number of collected votes was 220 votes, of which 200 were qualified (reaching 85.1\%). The author conducted the research by the quantitative method through data processing tools which are SPSS 25 software, exploratory factor analysis (EFA). The scale is tested by Cronbach's Alpha reliability coefficient and exploratory factor analysis (EFA). Scales and models are tested in accordance with parameters (Chi-square, degree of freedom, p-value, indicators of CFI, GFI, TLI and RMSEA), composite reliability, total variance explained, monism, convergent validity and discriminant validity. The demographic variable is demonstrated as below:

Table 1. Demographic variables

\begin{tabular}{|c|c|c|c|}
\hline \multirow{4}{*}{ Gender } & & $\mathbf{N}$ & $\%$ \\
\hline & Male & 92 & 46 \\
\hline & Female & 108 & 54 \\
\hline & Total & 200 & 100 \\
\hline \multirow[t]{4}{*}{ Academic rank } & Professor & 6 & 3 \\
\hline & Associate Professor & 37 & 18.5 \\
\hline & None & 157 & 78.5 \\
\hline & Total & 200 & 100 \\
\hline \multirow[t]{2}{*}{ Academic title } & Doctor & 200 & 100 \\
\hline & Total & 200 & 100 \\
\hline \multirow[t]{5}{*}{ Working experience } & Less than 10 years & 58 & 29 \\
\hline & $11-20$ years & 89 & 44.5 \\
\hline & $21-30$ years & 42 & 21 \\
\hline & More than 30 years & 11 & 5.5 \\
\hline & Total & 200 & 100 \\
\hline
\end{tabular}

There is a difference in the number of lecturers divided by gender participating in the survey between male and female. Accordingly, the number of female lecturers is higher than that of male lecturers, specifically: 108/200 people (accounting for 54\%) compared to 54/200 people (accounting for $46 \%$ ). The number of lecturers holding a doctoral degree without the academic rank of professor/associate professor participating in the survey is in the majority with $157 / 200$ people (accounting for $78.5 \%$ ) compared to the number of lecturers holding the academic rank of professor/associate professor with 43/200 people (accounting for $21.5 \%$ ). For the working experience, the number of lecturers participating in the survey with $11-20$ years of working experience accounts for the majority with $89 / 200$ people (accounting for $44.5 \%$ ) compared to other 
subjects: Less than 10 years (58/200 people, accounting for $21 \%$ ) and more than 30 years (11/200 people, accounting for 5.5\%).

\section{Results and discussion}

\subsection{Testing the reliability of scales and} correlated indicators

The results of testing the reliability of Cronbach's Alpha of the scales is shown as below:

Table 2. Results of Cronbach's Alpha of the scales

\begin{tabular}{|c|c|c|c|}
\hline No. & Notation & $\begin{array}{c}\text { Corrected Item - Total } \\
\text { Correlation }\end{array}$ & $\begin{array}{c}\text { Cronbach's } \\
\text { Alpha if item } \\
\text { deleted }\end{array}$ \\
\hline \multicolumn{4}{|c|}{ Cronbach's Alpha $=.933$ of P1a to P1i variables - Acquiring information / knowledge } \\
\hline 1 & $\mathrm{P} 1 \mathrm{a}$ & .745 & .926 \\
\hline 2 & $\mathrm{P} 1 \mathrm{~b}$ & .753 & .925 \\
\hline 3 & $\mathrm{P} 1 \mathrm{c}$ & .804 & .922 \\
\hline 4 & P1d & .808 & .922 \\
\hline 5 & P1e & .753 & .925 \\
\hline 6 & P1f & .794 & .923 \\
\hline 7 & P1g & .686 & .930 \\
\hline 8 & P1h & .705 & .929 \\
\hline 9 & P1i & .737 & .926 \\
\hline \multicolumn{4}{|c|}{ Cronbach's Alpha = .936 of P2a to P2h variables - Transferring knowledge } \\
\hline 1 & $\mathrm{P} 2 \mathrm{a}$ & .713 & .932 \\
\hline 2 & $\mathrm{P} 2 \mathrm{~b}$ & .785 & .927 \\
\hline 3 & $\mathrm{P} 2 \mathrm{c}$ & .772 & .928 \\
\hline 4 & $\mathrm{P} 2 \mathrm{~d}$ & .802 & .925 \\
\hline 5 & $\mathrm{P} 2 \mathrm{e}$ & .815 & .924 \\
\hline 6 & $\mathrm{P} 2 \mathrm{f}$ & .785 & .927 \\
\hline 7 & $\mathrm{P} 2 \mathrm{~g}$ & .792 & .926 \\
\hline 8 & $\mathrm{P} 2 \mathrm{~h}$ & .740 & .930 \\
\hline
\end{tabular}




\begin{tabular}{cccc} 
Cronbach's Alpha =.943 of P3a to P3h variables - Process of applying knowledge & \\
\hline 1 & P3a & .826 & .933 \\
2 & P3b & .698 & .943 \\
3 & P3c & .781 & .937 \\
4 & P3d & .774 & .937 \\
5 & P3e & .831 & .933 \\
6 & P3f & .844 & .932 \\
7 & P3g & .817 & .934 \\
8 & P3h & .819 & .934
\end{tabular}

Cronbach's Alpha $=.941$ of P4a to P4i variables - Process of protecting / preserving knowledge

\begin{tabular}{|c|c|c|c|}
\hline 1 & $\mathrm{P} 4 \mathrm{a}$ & .753 & .936 \\
\hline 2 & $\mathrm{P} 4 \mathrm{~b}$ & .748 & .936 \\
\hline 3 & $\mathrm{P} 4 \mathrm{c}$ & .815 & .932 \\
\hline 4 & $\mathrm{P} 4 \mathrm{~d}$ & .808 & .933 \\
\hline 5 & $\mathrm{P} 4 \mathrm{e}$ & .854 & .930 \\
\hline 6 & $\mathrm{P} 4 \mathrm{f}$ & .715 & .938 \\
\hline 7 & $\mathrm{P} 4 \mathrm{~g}$ & .825 & .932 \\
\hline 8 & $\mathrm{P} 4 \mathrm{~h}$ & .701 & .939 \\
\hline 9 & $\mathrm{P} 4 \mathrm{i}$ & .754 & .936 \\
\hline \multicolumn{4}{|c|}{ Cronbach's Alpha $=.962$ of P5a to P5e variables - Job satisfaction } \\
\hline 1 & P5a & .879 & .955 \\
\hline 2 & $\mathrm{P} 5 \mathrm{~b}$ & .895 & .952 \\
\hline 3 & $\mathrm{P} 5 \mathrm{c}$ & .911 & .950 \\
\hline 4 & $\mathrm{P} 5 \mathrm{~d}$ & .900 & .952 \\
\hline 5 & $\mathrm{P} 5 \mathrm{e}$ & .877 & .955 \\
\hline
\end{tabular}




\begin{tabular}{cccc} 
Cronbach's Alpha =.920 of P6a to P6d variables - Productivity of individual work performance \\
\hline 1 & P6a & .782 & .908 \\
2 & P6b & .833 & .890 \\
3 & P6c & .824 & .893 \\
4 & P6d & .825 & .893 \\
\hline
\end{tabular}

Cronbach's Alpha =.919 of P7a to P7d variables - Quality of individual work performance

\begin{tabular}{llcc}
\hline 1 & P7a & .813 & .895 \\
2 & P7b & .860 & .879 \\
3 & P7c & .779 & .907 \\
4 & P7d & .808 & .897
\end{tabular}

Analysis of Cronbach's Alpha test results shows that: Firstly, all scales meet the requirements with Cronbach's Alpha in the range of 0.919 to 0.962 . That is, the scale is at a very good level. Secondly, the corrected item total correlation of the measured variable in this scale is guaranteed to be greater than 0.3 (reaching from 0.686 - 0.911) and the scale has its high reliability. Thirdly, Cronbach's Alpha If Item Deleted coefficients are all smaller than the corrected item - total correlations, so all above variables can be kept. The above results show that: The scales with designed and built items have met the rigorous requirements of the test and can be absolutely used to conduct higher analysis.

\subsection{Exploratory factor analysis (EFA)}

The EFA test results for the scales are shown in the following table:

Table 3. EFA test results for the scales

\begin{tabular}{|c|c|c|c|c|c|}
\hline \multirow[t]{2}{*}{ Observed variables } & & & $\mathbf{F a}$ & & \\
\hline & 1 & 2 & 3 & 4 & 5 \\
\hline $\mathrm{P} 2 \mathrm{~g}$ & .754 & & & & \\
\hline $\mathrm{P} 2 \mathrm{e}$ & .751 & & & & \\
\hline $\mathrm{P} 2 \mathrm{c}$ & .706 & & & & \\
\hline $\mathrm{P} 2 \mathrm{~d}$ & .636 & & & & \\
\hline
\end{tabular}




\begin{tabular}{|c|c|c|c|c|}
\hline $\mathrm{P} 3 \mathrm{~b}$ & .628 & & & \\
\hline $\mathrm{P} 3 \mathrm{a}$ & .569 & & & \\
\hline $\mathrm{P} 2 \mathrm{~b}$ & .557 & & & \\
\hline $\mathrm{P} 3 \mathrm{c}$ & .518 & & & \\
\hline $\mathrm{P} 2 \mathrm{a}$ & & & & \\
\hline $\mathrm{P} 1 \mathrm{~d}$ & & .782 & & \\
\hline $\mathrm{P} 1 \mathrm{c}$ & & .736 & & \\
\hline $\mathrm{P} 1 \mathrm{e}$ & & .720 & & \\
\hline $\mathrm{P} 1 \mathrm{~b}$ & & .695 & & \\
\hline $\mathrm{P} 1 \mathrm{i}$ & & .667 & & \\
\hline P1f & & .661 & & \\
\hline P1a & & .622 & & \\
\hline P1g & & .599 & & \\
\hline $\mathrm{P} 1 \mathrm{~h}$ & & .580 & & \\
\hline $\mathrm{P} 5 \mathrm{~b}$ & & & .819 & \\
\hline $\mathrm{P} 5 \mathrm{e}$ & & & .796 & \\
\hline $\mathrm{P} 5 \mathrm{a}$ & & & .790 & \\
\hline $\mathrm{P} 5 \mathrm{c}$ & & & .785 & \\
\hline $\mathrm{P} 5 \mathrm{~d}$ & & & .777 & \\
\hline $\mathrm{P} 4 \mathrm{~h}$ & & & & .686 \\
\hline $\mathrm{P} 4 \mathrm{i}$ & & & & .669 \\
\hline $\mathrm{P} 3 \mathrm{e}$ & & & & .647 \\
\hline P3f & & & & .614 \\
\hline $\mathrm{P} 3 \mathrm{~d}$ & & & & .594 \\
\hline $\mathrm{P} 4 \mathrm{e}$ & & & & .554 \\
\hline $\mathrm{P} 2 \mathrm{~h}$ & & & & .539 \\
\hline
\end{tabular}




\begin{tabular}{|c|c|c|c|c|c|}
\hline $\mathrm{P} 3 \mathrm{~g}$ & & & & .520 & \\
\hline $\mathrm{P} 3 \mathrm{~h}$ & & & & .501 & \\
\hline $\mathrm{P} 4 \mathrm{f}$ & & & & & .665 \\
\hline $\mathrm{P} 4 \mathrm{c}$ & & & & & .597 \\
\hline $\mathrm{P} 4 \mathrm{~d}$ & & & & & .588 \\
\hline $\mathrm{P} 4 \mathrm{~g}$ & & & & & .584 \\
\hline $\mathrm{P} 4 \mathrm{~b}$ & & & & & .584 \\
\hline Eigenvalues & 22.705 & 22.705 & 22.705 & 22.705 & 22.705 \\
\hline $\begin{array}{l}\text { Total variance } \\
\text { explained }\end{array}$ & 17.525 & 34.283 & 49.403 & 64.416 & 74.897 \\
\hline KMO coefficient & & & & .964 & \\
\hline \multirow[t]{3}{*}{ Bartlett's test } & & Chi-Square & & 8164.519 & \\
\hline & & $D f$ & & 741 & \\
\hline & & Sig. & & .000 & \\
\hline
\end{tabular}

The EFA test results show that:

Firstly, with a KMO coefficient of $0.964(0.5<$ KMO $<1)$; Bartlett's test has a value of 0.000 , less than 0.05; Factor loading coefficient is greater than 0.5 and Eigenvalues of all 4 factors are greater than 1 , showing the convergence of factors. Thus, factor analysis is accepted with the research data set.

Secondly, the total variance explained is $74.897 \%$, greater than $50 \%$, showing that the factor analysis model is appropriate. This result shows that the above 5 factors successfully explain $74.897 \%$ of the variability of the data.

Thus, the results of the rotation matrix of the scale through Table 3 above show that 45 observed variables are grouped into the following 5 groups of independent factors: (1) Acquiring information/knowledge; (2) Transferring knowledge; (3) Process of applying knowledge; (4) Process of protecting/preserving knowledge; (5) Job satisfaction. In which, no items are eliminated or have to be adjusted to other groups of factors.

The elimination of redundant and inappropriate variables is done by identifying two-factor observed variables with high correlation values and reviewing the theoretical background. In this study, there are no variables in the two groups of factors, so it is not required to eliminate any variables. The other observed variables in this component are all appropriate to be used in the EFA analysis.

\subsection{Confirmatory Factor Analysis}


Table 4. Results of Confirmatory Factor Analysis of the scales

\begin{tabular}{|c|c|c|c|c|c|c|}
\hline Concept & Factor & $\begin{array}{l}\text { The } \\
\text { Number of } \\
\text { Observed } \\
\text { Variables }\end{array}$ & $\begin{array}{l}\text { Composite } \\
\text { Reliability } \\
\quad(\rho c)\end{array}$ & $\begin{array}{l}\text { Total } \\
\text { variance } \\
\text { explained } \\
\text { ( } \rho v c)\end{array}$ & $\begin{array}{l}\text { Reliability } \\
\text { of Alpha } \\
(\alpha)\end{array}$ & Adequacy \\
\hline \multirow{10}{*}{$\begin{array}{l}\text { Knowledge } \\
\text { Management }\end{array}$} & \multicolumn{5}{|c|}{$\begin{array}{l}\chi^{2}=638,087 \quad(p=0,000) ; \mathrm{df}=244 ; \text { Chi-square } / \mathrm{df}=2,615 \\
\mathrm{TLI}=0,954 ; \mathrm{GFI}=0,926 ; \mathrm{CFI}=0,959 ; \text { và } \mathrm{RMSEA}=0,049\end{array}$} & \multirow[t]{10}{*}{ Qualified } \\
\hline & \multirow[t]{3}{*}{$\begin{array}{l}\text { Acquiring } \\
\text { information/ } \\
\text { knowledge }\end{array}$} & \multicolumn{4}{|c|}{$\begin{array}{l}\chi 2=17,712 \quad(\mathrm{p}=0,023) ; \quad \chi 2 / \mathrm{df}=2.214 ; \\
\text { TLI }=0,988 ; \quad \text { GFI }=0,991 ; \quad \text { CFI }=0,994 ; \text { và } \\
\text { RMSEA }=0,043\end{array}$} & \\
\hline & & 3 & 0,7945 & 0,5632 & 0,7503 & \\
\hline & & 3 & 0,8103 & 0,5876 & 0,7663 & \\
\hline & \multirow[t]{2}{*}{$\begin{array}{l}\text { Transferring } \\
\text { knowledge }\end{array}$} & \multicolumn{4}{|c|}{$\begin{array}{l}\chi 2=15,953 \quad(\mathrm{p}=0,043) ; \quad \chi 2 / \mathrm{df}=1,994 ; \\
\text { TLI }=0,993 ; \quad \text { GFI }=0,992 ; \quad \text { CFI }=0,996 ; \text { và } \\
\text { RMSEA }=0,039\end{array}$} & \\
\hline & & 6 & 0,8917 & 0,581 & 0,7583 & \\
\hline & \multirow[t]{2}{*}{$\begin{array}{l}\text { Process of } \\
\text { applying } \\
\text { knowledge }\end{array}$} & \multicolumn{4}{|c|}{$\begin{array}{l}\chi 2=15,057 \quad(\mathrm{p}=0,035) ; \quad \chi 2 / \mathrm{df}=2,151 ; \\
\text { TLI }=0,992 ; \quad \text { GFI }=0,992 ; \quad \text { CFI }=0,996 ; \text { và } \\
\text { RMSEA }=0,042\end{array}$} & \\
\hline & & 6 & 0,8873 & 0,5707 & 0,7507 & \\
\hline & \multirow{2}{*}{$\begin{array}{l}\text { Process of } \\
\text { protecting } / \\
\text { preserving } \\
\text { knowledge }\end{array}$} & \multicolumn{4}{|c|}{$\begin{array}{l}\chi 2=17,868 \quad(\mathrm{p}=0,013) ; \quad \chi 2 / \mathrm{df}=2,527 \\
\mathrm{TLI}=0,988 ; \quad \text { GFI }=0,991 ; \quad \mathrm{CFI}=0,994 ; \text { và } \\
\text { RMSEA }=0,042\end{array}$} & \\
\hline & & 6 & 0,8788 & 0,5479 & 0,7392 & \\
\hline \multirow[t]{2}{*}{ Satisfaction } & \multirow[t]{2}{*}{ Satisfaction } & \multicolumn{4}{|c|}{$\begin{array}{l}\chi 2=5,794 \quad(\mathrm{p}=0,043) ; \quad \chi 2 / \mathrm{df}=2,897 \\
\text { TLI }=0,993 ; \quad \text { GFI }=0,996 ; \quad \text { CFI }=0,998 ; \text { và } \\
\text { RMSEA }=0,053\end{array}$} & \multirow[t]{2}{*}{ Qualified } \\
\hline & & 4 & 0,9047 & 0,7040 & 0,8383 & \\
\hline \multirow[t]{2}{*}{$\begin{array}{l}\text { Task } \\
\text { Performance }\end{array}$} & \multicolumn{5}{|c|}{$\begin{array}{l}\chi^{2}=16,535 \quad(\mathrm{p}=0,000) ; \quad \chi 2 / \mathrm{df}=2,067 ; \quad \mathrm{TLI}=0,984 ; \\
\mathrm{GFI}=0,992 ; \mathrm{CFI}=0,991 ; \text { và } \mathrm{RMSEA}=0,040\end{array}$} & \multirow[t]{2}{*}{ Qualified } \\
\hline & $\begin{array}{l}\text { Productivity } \\
\text { of individual } \\
\text { work } \\
\text { performance }\end{array}$ & 3 & 0,7127 & 0,4549 & 0,6713 & \\
\hline
\end{tabular}




\begin{tabular}{|l|l|l|l|l|l|l|}
\hline & $\begin{array}{l}\text { Quality of } \\
\text { individual } \\
\text { work } \\
\text { performance }\end{array}$ & 3 & 0,7377 & 0,4852 & 0,6947 & \\
\hline
\end{tabular}

Correlation between variables ranges from 0.314 to 0.828 ; SE from 0.015 to 0.03 ; (1-r)/SE between 7.4 and 45,$733 ; \mathrm{p}=0.000$; with $\chi^{2} / \mathrm{df}<3$; GFI, CFI, TLI values $>0.9$; RMSEA $<0.08$, ensuring discriminant validity between concepts. In general, the test results show that the knowledge management scale has components (knowledge creation, knowledge acquisition, knowledge transfer, knowledge application...), job satisfaction scale. ensure convergent validity, ensure reliability and discriminant validity, consistent with the obtained data. The job completion scale ensures convergent value, reliability, data fit, two components of productivity and quality, with a slightly low discriminant value ( $\rho v c)$ but acceptable to discriminant value.

\subsection{The results of testing the measurement model, research model and hypothesis}

The results of testing the appropriate measurement model, specifically: $\chi 2=961,363$; $\mathrm{df}=494 ;(\mathrm{p}=0.000) ; \chi 2 / \mathrm{df}=1.946 ; \mathrm{GFI}=0.920$; $\mathrm{TLI}=0.959 ; \mathrm{CFI}=0.963$; and $\mathrm{RMSEA}=0.038$. The SEM results of the research model show that the research model has 512 degrees of freedom, $\chi 2=1,015,575(\mathrm{p}=0.000) ; \chi 2 / \mathrm{df}=1.984 ; \mathrm{GFI}=$ 0.916 ; TLI $=0.957$; CFI $=0.961$; and RMSEA $=$ 0.042 shows that this research model is suitable with the data.

Table 5. Results of testing the causal relationship between the concepts in the research model

\begin{tabular}{|l|c|c|c|c|c|}
\hline Relationship & $\begin{array}{c}\text { Unstandardized } \\
\text { Coefficients }\end{array}$ & $\begin{array}{c}\text { Standardized } \\
\text { Coefficients }\end{array}$ & S.E & C.R & P \\
\hline Satisfaction $\leftarrow \begin{array}{c}\text { Knowledge } \\
\text { Management }\end{array}$ & 0,840 & 0,580 & 0,070 & 11,996 & $* * *$ \\
\hline Assigned job performance $\leftarrow$ Satisfaction & 0,210 & 0,356 & 0,037 & 5,720 & $* * *$ \\
\hline Task performance & 0,269 & 0,314 & 0,054 & 5,011 & $* * *$ \\
Kanagement & Knowledge & & & \\
\hline
\end{tabular}

\subsection{Result of hypothesis testing}

The estimated results in the analysis of linear structural model SEM show that the relationship between knowledge management and job satisfaction and job completion is statistically significant $(p<0.01)$. $)$. The results of the hypothesis testing are as follows:

H1: Knowledge management has a direct and positive impact on job satisfaction $(\beta=0.580$; S.E. $=0.066 ; p=0.000)$. The research results support the results of Lee and Chang (2007), Kulkarni et al. (2007), Singh and Sharma (2010),
Almahamid et al. (2010), Kianto et al. (2016). Research results do not support the study of Koseoglu et al (2010) on the impact of knowledge management on job satisfaction.

$\mathrm{H} 2$ : Job satisfaction has a direct and positive impact on job completion results $(\beta=0.356$; S.E. $=0.036 ; \mathrm{p}=0.000)$. The research results are consistent with the results of Judge et al. (2001), Pushpakumari (2008), Hira and Waqas (2012), Yang and Hwang (2014), Dinc and Plakalovic (2016), Chen et al. (2017) on the impact of job satisfaction on job performance. The study does not support the conclusion of Organ (1977) that 
job completion is measured in a narrow range (including: Work volume and quality) is not correlated with job satisfaction. Work.

$\mathrm{H} 3$ : knowledge management has a direct and positive impact on job completion results $(\beta=$ 0.288 ; S.E. $=0.05 ; \mathrm{p}=0.000)$. The research results support the research results of Chi et al (2010); Tseng and Huang (2011), Tarhini (2016), Hoang Hai Yen (2015), Balasubramanian et al (2019), Shafique et al (2018) on the impact of knowledge management on job performance. This study adds: knowledge management not only has a direct positive impact on job completion, but also has an indirect impact on job completion through job satisfaction ( $\beta$ directly). direct $=$ $0.288 ; \beta$ indirect $=0.206 ; \beta$ total $=0.494$.

\section{Conclusions and implications}

\subsection{Conclusions}

Knowledge management in universities is demonstrated through the following 5 basic factors: (1) Acquiring information/knowledge; (2) Transferring knowledge; (3) Process of applying knowledge; (4) Process of protecting/preserving knowledge; (5) Job satisfaction and 45 items / indicators are shown. Both qualitative and quantitative research results show that the determination of the above factors and indicators is completely appropriate (results of rotation matrix).

The study of the author has developed a model combining three concepts of knowledge management, job satisfaction and job performance. Job satisfaction (teaching and

\section{References}

[1] Apurva and Singh, "Understanding knowledge management: a literature review," Int. J. Eng. Sci. Technol, 3 (2), pp. 926-939, 2011.

[2] Petrash, Gordon, "Dow's journey to a knowledge value management culture," European Management Journal, Elsevier, vol. 14(4), pages 365-373, 1996.

[3] Inese Mavlutova, Kristaps Lesinskis, Mindaugas Liogys, Janis Hermanis, Innovative Teaching Techniques for research) plays a partial mediating role in the relationship between knowledge management and the job performance of lecturers.

The scale of impact of knowledge management on job satisfaction and job performance of lecturers has been standardized and satisfied the rigorous requirements of the test. Therefore, this scale can be used in subsequent studies with similar models.

In terms of practice, this study has determined that knowledge management has a positive impact on the satisfaction and job performance of lecturers, helping university administrators to come up with measures for improvement of knowledge management to enhance satisfaction and job performance of lecturers and improve the performance of the universities.

\subsection{Implications}

The study of the author on the impact of knowledge management on job satisfaction and job performance of lecturers in the universities is specific suggestions for management and leadership in the scope of the university. These are: Lecturers are the key workforce in the university; Job satisfaction and job performance of lecturers are the basis and conditions creating quality and effectiveness of the university. Due to the strong and positive impact of knowledge management factor on job satisfaction and job performance of lecturers, the university administrators should be aware of the influencing factors, calculate and select the most appropriate methods and solutions for management and leadership, avoid negative effects and mistakes.

Entrepreneurship Education in the Era of Digitalisation, pp. 725-733, WSEAS Transactions on Environment and Development, Volume 16, 2020.

[4] László Berényi, Nikolett Deutsch, Assessment of the Future Role of Some Energy Sources by Higher Education Students in Hungary, pp. 689-698, WSEAS Transactions on Environment and Development, Volume 16, 2020. 
[5] Juan Carlos Chancusig Chisag, Melquiades Mendoza Perez, Olga Lorena Gonzalez Ortiz, Oscar Alejandro Guaypatin Pico, Roberto Carlos Arias Figueroa, Manuel William Villa Quishpe, Systemic Model of Implementation of the Blended Learning Modality in the Social Sciences and Education Careers at the Ecuadorian University, pp. 660-670, WSEAS Transactions on Environment and Development, Volume 16, 2020.

[6] Patricia Marybelle Davies, Phil Weir, Sarah Byrne, Building Educational Simulations using KSA Open Data, WSEAS Transactions on Environment and Development, pp. 802-810, Volume 16, 2020

[7] Sharma, R. D., \& Jyoti, J, "Job satisfaction of university teachers: an empirical study," Journal of Services Research, 9(2), pp.5180, 2009.

[8] Kianto, A., Vanhala, M., \& Heilmann, P, "The impact of knowledge management on job satisfaction," Journal of Knowledge Management, 20(4), pp. 621-636, 2016.

[9] Gibbs, T., \& Ashill, J, “The effects of high performance work practices on job outcomes: Evidence from frontline employees in Russia," International Journal of Bank Marketing, 31(4), pp. 305-326, 2013.

[10] Yang, C. L., \& Hwang, M, "Personality traits and simultaneous reciprocal influences between job performance and job satisfaction," Chinese Management Studies, 8(1), pp.6-26, 2014.

[11] Tran Kim Dung, "Human Resource Management," Publishing House of Economics, Ho Chi Minh City, 2015.

[12] Tseng, S., \& Huang, J, "The correlation between Wikipedia and knowledge sharing on job performance," Expert Systems with Applications, 38(5), pp.6118-6124, 2011.
[13] Hoang Hai Yen, "Impact of knowledge management and business ethics environment on job performance of bank employees," Thesis of Doctor of Economics, University of Economics Ho Chi Minh City, 2015

[14] Koopmans, L., Bernaards, C. M., Hildebrandt, V. H., Schaufeli, W. B., de Vet Henrica, C. W., \& van der Beek, A. J, "Conceptual frameworks of individual work performance," Journal of Occupational and Environmental Medicine, 53(8), pp. 856866, 2011.

[15] Almahamid, S., McAdams, A., \& Kalaldeh, $\mathrm{T}$, "The relationships among organizational knowledge sharing practices, employees' learning commitments, employees' adaptability and employees' job satisfaction: An empirical investigation of the listed manufacturing companies in Jordan,' Interdisciplinary Journal of Information, Knowledge, and Management, Vol. 5, pp. 327-356, 2010.

[16] Balasubramanian, S, Al-Ahbabi, S., \& Sreejith, S, "Knowledge management processes and performance: The impact of ownership of public sector organizations," International Journal of Public Sector Management, Vol. 33 No. 1, pp.1-21,2019.

[17] Best, E. E, "Job satisfaction of teachers in Krishna primary and secondary schools. (3212536 Ed.D.), The University of North Carolina at Chapel Hill, United States -North Carolina," Journal of Science, No. 2013, pp. 91-100, 2006.

[18] Billingsley, B. S, "Special Education Teacher Retention and Attrition: A Critical Analysis of the Research Literature," The Journal of Special Education, Vol. 38 No. 1, pp. 39-55, 2004.

[19] Chen, J. C., Wu, C. H., \& Chen, S. I, “A study into the impact of employee wellness and job satisfaction on job performance," The International Journal of Organizational Innovation, 10(2), 2017.

\section{Creative Commons Attribution License 4.0 (Attribution 4.0 International, CC BY 4.0)}

This article is published under the terms of the Creative Commons Attribution License 4.0

https://creativecommons.org/licenses/by/4.0/deed.en_US 